\title{
COMPUTER SIMULATION AS AN EXAMPLE OF THE USE OF MODERN EDUCATIONAL AIDS IN TECHNICAL EDUCATION
}

\section{Dorota JEDRASIK}

\begin{abstract}
Virtual reality it one from most quickly improved computing having the show for the task of the world we live in the form of computer programs. Thanks to technological new solutions simulation programs more and more in reality are copying reality of phenomena. This method consists in giving appropriate incentives stimulating, being aimed possibly to all senses into the way as most faithful copying the reality of the happening occurrence. A computer simulation has both positive and negative teaching advantages. However, as one of few methods, at present is being regarded most universal and useful in didactics.
\end{abstract}

Key words: computer simulation, computer assisting in didactics

\section{SYMULACJA KOMPUTEROWA JAKO PRZYKLAD WYKORZYSTANIA NOWOCZESNYCH ŚRODKÓW DYDAKTYCZNYCH W KSZTAŁCENIU TECHNICZNYM}

Streszczenie: Rzeczywistość wirtualna to jedna z najszybciej udoskonalanych technik komputerowych mających za zadanie przedstawienie otaczającej nas rzeczywistości w postaci programów komputerowych. Dzięki nowym rozwiązaniom technologicznym programy symulacyjne coraz bardziej realnie odwzorowują rzeczywistość zjawisk. Metoda ta polega na podawaniu możliwie wszystkim zmysłom odpowiednich bodźców stymulujących, mających na celu w sposób jak najwierniejszy odwzorowanie realności zachodzącego zjawiska. Symulacja komputerowa posiada zarówno pozytywne jak i negatywne walory dydaktyczne. Jednak, jako jedna z nielicznych metod, jest obecnie uznawana za najbardziej uniwersalną i przydatną w dydaktyce.

Slowa kluczowe: symulacja komputerowa, komputerowe wspomaganie w dydaktyce

\section{Wstęp}

Rozwój techniki we wszelkich dziedzinach nauki i kultury na świecie, oparty szczególnie na rozwoju informatyki, wymaga wykształcenia nowego pokolenia, które spełniłoby oczekiwania wymagającego rynku pracy. Stwierdzenie, że „człowiek uczy się całe życie” nie jest też obce dla tych wszystkich, którzy już pracują i zmuszeni są uzupełniać swoje kwalifikacje odpowiednio do nowych zadań. Stąd zachodzi potrzeba ciągłej edukacji opartej na najnowszych zdobyczach techniki umożliwiającej głębszą analizę materiału i jego przyswojenia $[13,10]$. Wprowadzenie nowoczesnych środków dydaktycznych podczas pracy w szkole zwiększa zainteresowanie młodych ludzi zdobywaniem wiedzy, chęci do aktywnego uczestnictwa w zespole, w klasie i w domu, przy pracy i zabawie. Celem pracy jest przekazanie czytelnikowi uzyskanych wniosków w wyniku wieloletniej obserwacji oraz praktyki dydaktycznej na poziomie szkoły średniej o profilu technicznym [9].

\section{Cel i zakres pracy}

Realizacja zajęć informatycznych w szkole wymaga niezwykle starannie dobranych pomocy naukowych $\mathrm{w}$ postaci infrastruktury technicznej w pracowni oraz oprogramowania dydaktycznego. Klasa jest zbiorem uczniów o indywidualnych cechach osobowości, które mają istotny wpływ na indywidualne predyspozycje ucznia $\mathrm{w}$ zaangażowaniu się $\mathrm{w}$ proces dydaktyczny [22]. Niestety, obecna forma kształcenia w szkole jest formą organizacji procesu kształcenia odbiegającą w sposób istotny od szeroko popularyzowanej idei kształcenia uwzględniającego indywidualność ucznia. System klasowy, niestety narzuca pewną standaryzację nauczania opartą na założeniu, iż każdy $\mathrm{z}$ uczniów posiada podobne predyspozycje w sferze poznawczej $\mathrm{i}$ intelektualnej. Jest to błąd $\mathrm{z}$ punktu pedagogicznego $\mathrm{W}$ odniesieniu do systemu kształcenia, ponieważ jak doskonale wiemy każdy z uczniów charakteryzuje się pewną odmiennością wyrażaną $\mathrm{w}$ indywidualnym podejściu do nauki [19]. Z drugiej strony, praca grupowa daje duże szanse uczniom mniej 
uzdolnionym, którzy pracując w grupie doświadczają wsparcia w nauce oraz uczestniczą w sytuacjach problemowych w grupie. Problem efektywności nauczania jest na tyle obszerny, iż wykracza znacząco poza obszar niniejszych rozważań pracy. Odsyłam czytelnika do licznych publikacji $[12,16,20]$. Ponieważ jako pedagog funkcjonujący zawodowo $w$ realiach dzisiejszej szkoły, dbając o poziom kształcenia w obszarze własnych zainteresowań, postanowiłam dokonać głębszej analizy problemu i na podstawie własnych efektów badań przeprowadziłam badania naukowe, oparte wprawdzie na podstawach metodologii pedagogicznej jednak, których wyniki są na tyle istotne iż warto o nich wspomnieć.

\section{Efektywność dydaktyczna programów symulacyjnych $w$ procesie ksztalcenia}

Ma ona za zadanie stworzenie pewnego modelu, którym będzie można tak sterować, aby w efekcie końcowym dokonać oceny poprawnego działania tworzonego systemu. Symulacja komputerowa jest efektem finalnym połączenia modelu fizycznego i matematycznego. Po wprowadzeniu danych odnośnie obiektu i zapisaniu obliczeń w programie symulacyjnym możemy dokonać wizualizacji, na której nam zależy. Najbardziej przydatne są techniki symulacyjne przy wykorzystaniu technik złożonych, gdzie analityczne wyznaczanie rozwiązania jest zbyt pracochłonne [18,21]. Największą zaletą symulacji komputerowej jest możliwość obserwowania przyszłości. Jest ona bardzo istotna, ponieważ symulację taką możemy przetestować bez angażowania wszelkich zasobów. Możemy sterować czasem trwania symulacji, mamy możliwość prześledzenia całego zdarzenia krok po kroku a dzięki wizualizacji skomplikowane systemy stają się łatwiejsze odbiorze $[23,14]$.

\begin{tabular}{|c|c|c|}
\hline $\begin{array}{c}\text { Zdolność } \\
\text { samodzielnego } \\
\text { uczenia się }\end{array}$ & $\begin{array}{c}\text { Opanowanie } \\
\text { wiadomości i } \\
\text { umiejętności }\end{array}$ & $\begin{array}{c}\text { Zaufanie do } \\
\text { własnych procesów } \\
\text { poznawczych }\end{array}$ \\
\hline \multicolumn{3}{|c|}{ EFEKTY DYDAKTYCZNE } \\
\hline \multicolumn{3}{|c|}{ MODEL SYMULACJI } \\
\hline \multicolumn{3}{|c|}{ EFEKTY WYCHOWAWCZE } \\
\hline $\begin{array}{c}\text { Wykorzystanie } \\
\text { informacji } \\
\text { zwrotnych }\end{array}$ & $\begin{array}{c}\text { Niezależność w roli } \\
\text { ucznia }\end{array}$ & $\begin{array}{c}\text { Wrażliwość na } \\
\text { związki } \\
\text { przyczynowo- } \\
\text { skutkowe }\end{array}$ \\
\hline
\end{tabular}

Tabela 1 Dydaktyczne i wychowawcze efekty modelu symulacji [źródto: BRUCE J., CALHOUN E., HOPKINS D. 1999]

\section{Cel i zakres badań}

Badania nad efektywnością nauczania prowadzone są w oparciu o metodologię badań pedagogicznych. Metodologia ta prowadzi do weryfikacji postawionych hipotez. Które są odpowiedzią na problem badawczy. Celem moich badań jest ocena stosowanych narzędzi dydaktycznych, metod nauczania oraz techniki przekazu wiedzy podczas zajęć. Główny problem, jaki postawiłam sobie za cel poznania to uzyskani odpowiedzi na następujące pytanie: czy stosowane przeze mnie pomoce naukowe i wprowadzone innowacje podczas zajęć mają istotny wpływ na poziom kształcenia przejawiający się wzrostem efektywności nauczania w poszczególnych klasach? Odpowiedź na dany problem może być dokonany poprzez weryfikację założeń głównej tezy, która brzmi: Nowoczesne pomoce naukowe oparte na programach symulacyjnych mają istotny wpływ na wzrost efektywności nauczania w wybranych klasach. W tym momencie należy wspomnieć, iż celem pracy każdego nauczyciela powinna być dbałość o jakość kształcenia. Przejawia się ona w końcowych wynikach semestralnych, ale w szerszym znaczeniu jest przejawem dbałości o poziom intelektualny absolwentów szkoły oraz co z tym jest ściśle związane, z szansą na sukces w przyszłej pracy zawodowej. Oczywiście przeprowadzone przeze nie badania mają charakter terytorialny, ograniczony do uczniów klas w których uczę, stąd uzyskane wnioski są obarczone są błędem jednak w odniesieniu do moich potrzeb nie są błędem na tyle istotnym aby je pominąć. Problem miejsca i roli symulacji w edukacji technicznej zostanie zbadany w kontekście wartości zmiennych jakościowych i zmiennych ilościowych oraz relacji między zmiennymi, co pozwoli uchwycić preferencje wybranych środków przekazu medialnego.

\section{Przebieg badań}

Badania dotyczyły klas technikum o profilu techniczno-informatycznym. W ramach zajęć uczniowie posługiwali się programami wspomagającymi proces poznawczy $\mathrm{w}$ postaci różnorodnych programów multimedialnych oraz symulacyjnych. Ze względu na obszerność poruszanych treści kształcenia, programy dobierane były na podstawie ich przydatności 
dydaktycznej oraz możliwości technicznych w pracowni laboratoryjnej [11]. Ze względu na rozbudowaną formę niektórych programów np.: ELI - laboratorium, zajęcia prowadzone były $\mathrm{w}$ grupach a więc wykorzystałam sytuację problemową opartą na współpracy wszystkich członków grupy. Efekty prac zostały ocenione i na ich podstawie dokonane zaliczenie przedmiotu. W ujęciu tematyki pracy, najistotniejsze wydają się uzyskane efekty pracy i badań, dlatego też pominięty zostanie opis całego etapu badań (analizy szczegółowej zajęć dydaktycznych) a jedynie skupię się na efekcie końcowym. Badania prowadzone były $\mathrm{w}$ ciągu całego roku szkolnego a więc od 3.09.2012 do 15.06.2013. Liczba uczniów objętych badaniami ograniczona była liczebnością klas trzecich i czwartych, łącznie objęto 98 osób. Ze względu na małą liczebność populacji, zrezygnowano $\mathrm{z}$ organizacji badań $\mathrm{w}$ formie grup porównawczych a przeprowadzone badania miały charakter pilotażowy dla przyszłych bardziej rozbudowanych badań naukowych, które można zweryfikować statystycznie.

Z hipotezy głównej wynikają następujące hipotezy szczegółowe:

H1: Nowoczesne środki dydaktyczne

wspomagane komputerowo w postaci programów symulacyjnych $\mathrm{w}$ sposób istotny wpływają na zakres wiedzy uczniów $w$ porównaniu z środkami dotychczas stosowanymi.

$H 2$ : Nowoczesne środki dydaktyczne

wspomagane komputerowo w postaci programów symulacyjnych $\mathrm{W}$ porównaniu $\mathrm{z}$ dotychczas stosowanymi środkami w istotny sposób wpływają na poziom zrozumienia wiedzy.

H3: Nowoczesne środki dydaktyczne

wspomagane komputerowo w postaci programów symulacyjnych $\mathrm{W}$ porównaniu $\mathrm{z}$ dotychczas stosowanymi środkami $\mathrm{W}$ istotny sposób wpływają na trwałość wiedzy.

W badaniach przyjęto techniki standaryzowane: kwestionariusz ankiety, wywiad, obserwacja. Podstawę do weryfikacji przyjętych hipotez stanowił kwestionariusz ankiety oraz testy sprawdzające wiedzę $\mathrm{z}$ danego przedmiotu. Pytania zawierają kryterium oceny: (zdecydowanie tak, raczej tak, nie, nie mam zdania).

\section{Analiza wyników badań}

Analiza uzyskanych wyników potwierdziła słuszność założonych hipotez szczegółowych, pomimo iż uzyskane zostały w formie ogólnej, bez uwzględnienia szczegółowej analizy zjawiska. Dały one jednak wyraźne wskazówki do oceny prowadzanych innowacji podczas kolejnych zajęć, są przesłanką motywującą do dalszych prac oraz wspaniałym podsumowaniem dla nauczyciela dotyczących jego efektywności dydaktycznej (wyk.1).

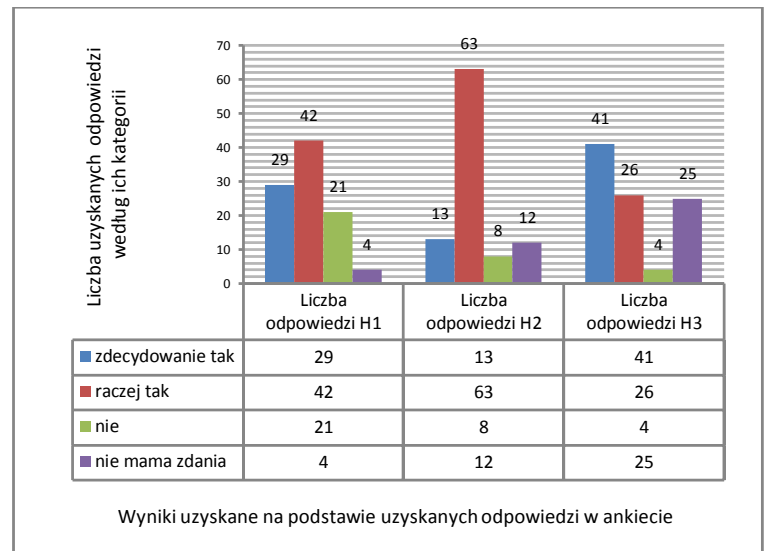

Wykres 1 Wyniki przeprowadzonych badań pilotażowych

\section{Podsumowanie}

Badania pilotażowe potwierdziły zakładane hipotezy, jednak analiza problemu musi być przeprowadzona $\mathrm{w}$ odniesieniu do badań jakościowych. Liczba odpowiedzi na podstawie kwestionariusza ankiety ukazała problem w postaci ilościowej a nie jakościowej. W tym przypadku warto również dokonać szczegółowej analizy odpowiedzi na podstawie kwestionariusza wywiadu oraz obserwacji, albowiem te dane wydają się w aspekcie praktyki dydaktycznej najistotniejsze. Obserwacja jest metodą trudno mierzalną jednak niezwykle istotną i wartościową. Nie wszystkie programy symulacyjne były trafnie dobrane, największe problemy dotyczyły niedostatecznej znajomości technicznego języka angielskiego albowiem najczęściej w takim języku oferowane było menu aplikacji. Również programy zbyt obszerne, wykorzystujące zbyt zaawansowane obliczenia matematyczne sprawiały uczniom trudność, spowalniały czas pracy oraz wprowadzały ogólny chaos. Dlatego też, zaistniała potrzeba wspomożenia pracy na zajęciach poprzez formę e-learningu a raczej b-learningu [15,17]. Dzięki materiałom dydaktycznym oraz możliwości pobrania aplikacji w wersji freeware online, uczniowie kontynuowali naukę w domu. Badania są nadal prowadzone a ostateczne wyniki zostaną poddane metodom statystycznym. 


\section{Literatura}

[1]BRUCE J., CALHOUN E., HOPKINS D.: Przykłady modeli uczenia się i nauczania. 1999, Warszawa - WSiP.

[2] FURMANEK, M. Społeczne aspekty oddziaływań technologii informacyjnych. 2003, Toruń.

[3] GOBAN-KLAS, T. SIENKIEWICZ, P. Społeczeństwo informacyjne. Szanse, zagrożenia, wyzwania. 1999, Kraków - Wydawnictwo Fundacji Postępu Telekomunikacji.

[4] JUSZCZYK， S. Człowiek w świecie elektronicznych mediów-szanse i zagrożenia. 2000, Katowice - Wydawnictwo Uniwersytetu Śląskiego.

[5]JUSZCZYK, S. Kształcenie na odległość elementem powszechnej edukacji medialnej w społeczeństwie informacyjnym. Edukacja medialna w społeczeństwie informacyjnym. 2003, Torun - Wydawnictwo Adam Marszałek.

[6] KĘDZIERSKA， B. Nauczyciel wobec technologii informacyjno-komunikacyjnych. Edukacja medialna w społeczeństwie informacyjnym. 2003, Toruń - Wydawnictwo Adam Marszałek.

[7]ŁASIŃSKI， G. Strategia prezentacji w procesie efektywnego komunikowania się. 1998 , II Międzynarodowa Konferencja Media a edukacja. Poznań.

[8] ŁASIŃSKI, G. Współczesne techniki informacyjne i ich wpływ na sposób prezentacji. Media w kulturze, nauce i oświacie. 1996, Tarnów.

[9] PRAUZNER, T. Applications of multimedia devices as teaching aids. Annales UMCS Informatica. 2010, Wydawnictwo Maria CurieSkłodowska University in Lublin 2010, s. 167175. DOI: 10.2478/v10065-012-0004-4, ISSN 1732-1360

[10] PRAUZNER, T. Bezpieczeństwo kulturowe a globalizm. Edukacja XXI wieku. Jakość wobec wyzwań i zagrożeń XXI wieku. 2010, Poznań Wydawnictwo Wyższej Szkoły Bezpieczeństwa, str. 340-344. ISBN 978-83-61304-21-0

[11] PRAUZNER, T. Blended learning : nowa metoda nauczania. Prace Naukowe Akademii im. Jana Długosza w Częstochowie. Edukacja Techniczna i Informatyczna. 2010, Wydawnictwo Akademii im. Jana Długosza w Częstochowie, s.109-114. ISSN 1897-4058, ISBN 978-83-7455-298

[12] PRAUZNER, T. Information Technology in Contemporary Education - Individuals' Researche. American Journal of Educational Research. 2013, Vol. 1, No. 10, 430-435, ISSN
(Print): 2327-6126, ISSN (Online): 2327-6150 online http://www.sciepub.com

[13] PRAUZNER, T. LifeLong Learning edukacja przez całe życie. Prace Naukowe AJD, Edukacja Techniczna i Informatyczna. 2011, Częstochowa - Wydawnictwo Akademii im. Jana Długosza w Częstochowie, s.163-170. ISSN 1897-4058

[14] PRAUZNER, T. Praktyczne wykorzystanie symulacji dźwięku w kształceniu technicznym studentów. Edukacja - Technika - Informatyka. 2013, Rzeszów - Wydawnictwo Oświatowe FOSHE, s. 314-319. ISBN 978-83-7586-043-6 ISSN 2080-9069

[15] PRAUZNER, T. Prawo a bezprawie w Internecie. Prace Naukowe AJD, Edukacja Techniczna i Informatyczna. 2009, Częstochowa - Wydawnictwo Akademii im. Jana Długosza w Częstochowie, ISSN 1897-4058

[16] PRAUZNER, T. Technologia informacyjna - wybrane problemy społeczne. Edukacja Technika - Informatyka. 2012, Rzeszów Wydawnictwo FOSZE, s.39-45. ISBN 978-837586-043-6, ISSN 2080-9069

[17] PRAUZNER, T. Tworzenie treści dydaktycznych w kształceniu e-learningowym w aspekcie prawnym. EduAkcja. Magazyn edukacji elektronicznej. 2013, str. 38-43, http://www.eduakcja.eu/ ISSN 2081-870X

[18] PRAUZNER, T. Zakłócenia elektromagnetyczne w elektronicznych systemach alarmowych. Przegląd Elektrotechniczny. 2012, s. 205-208. ISSN 0033-2097

[19] PRAUZNER, T. Zastosowanie komputera w edukacji - problemy psychologiczne. Wychowanie Techniczne w Szkole. 2004, s.1416. Warszawa - Agencja Wydawnicza BIS Bolesław Stefaniak. ISSN 0867-3985.

[20] PRAUZNER, T. Mapa myśli - nowoczesna technika zapisu i zarządzania informacją. Prace Naukowe AJD, Edukacja Techniczna i Informatyczna. 2008, Częstochowa Wydawnictwo Akademii im. Jana Długosza w Częstochowie, s. 225-230. ISSN 1897-4058

[21] PRAUZNER, T. Systemy monitoringu w inteligentnym budynku. Prace Naukowe AJD, Edukacja Techniczna i Informatyczna. 2012, Częstochowa - Wydawnictwo Akademii im. Jana Długosza w Częstochowie, str. 113-124, ISSN 1897-4058, ISBN 978-83-7455-298-1

[22] PRAUZNER, T. Wpływ nowoczesnych mass mediów na osobowość człowieka. Edukacja - Technika - Informatyka. 2010, Rzeszów - 
Wydawnictwo Oświatowe FOSZE, s.46-51. ISBN 978-83-7586-043-6 ISSN 2080-9069

[23] PRAUZNER, T. Zastosowanie programów symulacyjnych $\mathrm{w}$ nauczaniu przedmiotów technicznych. Prace Naukowe AJD, Edukacja Techniczna i Informatyczna. 2006, Częstochowa - Wydawnictwo Akademii im. Jana Długosza w Częstochowie, s.121-128. ISSN 1897-4058, ISBN 978-83-7455-298-1

[24] SIEMIENIECKA-GOGOLIN，D. Media a twórczość. Edukacja medialna w społeczeństwie informacyjnym. 2003, Torun - Wydawnictwo Adam Marszałek, s. 76.

[25] SIEMIENIECKI, B., LEWANDWOSKI, W. Internet w szkole. 1998, Torun - Wydawnictwo Adam Marszałek.

[26] SIEMIŃSKA, A. Współczesne formy multimedialnego przekazu informacji wykorzystywane w edukacji niestacjonarnej.
Edukacja medialna w społeczeństwie informacyjnym. 2003, Toruń - Wydawnictwo Adam Marszałek.

[27] STRYKOWSKI, W. Pedagogika i edukacja medialna $w$ społeczeństwie informacyjnym. Edukacja medialna w społeczeństwie informacyjnym. 2003, Torun - Wydawnictwo Adam Marszałek.

mgr inż. Dorota Jędrasik

Techniczne Zakłady Naukowe w Częstochowie

Adres kontakowy:

Dorota Jędrasik

Wąsosz 140a

42-274 Konopiska

E-mail: dorota.jedrasik@poczta.onet.pl

Tel. 604497965 